\title{
Positive improvement in palatability of metabolic formula with the use of miraculin protein in patients with inborn errors of metabolism and healthy adults
}

\section{Cambio positivo en la palatabilidad de la fórmula metabólica con el uso de la proteína miraculina en pacientes con errores innatos del metabolismo y adultos sanos}

\begin{abstract}
As palatability of medical formulas has been documented as unpleasant, new options are required to improve acceptance and adherence in people with inborn errors of metabolism (IEM). Miracle fruit (Synsepalum dulcificum) has a glycoprotein named miraculin that transforms a sour, bitter taste such as the one found in metabolic formula, into a sweet perception. The objective of this work is to analyze the response in the taste perception of metabolic formula with the use of the miraculin tablets in patients with IEM and healthy adults. To test this hypothesis a prospective, longitudinal, quasi-experimental, analytical study was performed. Patients with IEM and healthy adults were recruited. All participants assessed 3 different liquids (lemon, apple cider vinegar and metabolic formula) before and after the administration of miraculin tablets and completed a questionnaire. The sensory responses were evaluated using hedonic scales, analyzed with nonparametric tests for paired data. Seven patients with IEM and 14 healthy subjects were included. After miraculin intake $57 \%$ of patients $(Z \leq-1.89$ $p=0.059)$ and healthy adults $(Z \leq-2.31 p=0.021)$ had a positive change in their taste perception. The absolute frequency of patients who did not like the metabolic formula decreased from 4 to 1 , and in patients who liked it or loved, it increased from 0 to 2 and from 0 to 1 respectively; the frequency of patients who perceived the metabolic formula as indifferent or hated it, did not change. Response in taste perception had a positive change of $57 \%$ in both groups. The use of miraculin tablets may improve palatability of metabolic formula.
\end{abstract}

Key words: Inborn errors; Medical foods; Miracle fruit; Palatability; Synsepalum dulcificum.

\section{RESUMEN}

La palatabilidad de las fórmulas médicas se ha reportado como desagradable, se requieren nuevas opciones para mejorar la aceptación en personas con errores innatos del metabolismo (EIM). La fruta milagrosa (Synsepalum dulcificum) contiene una glucoproteína llamada miraculina que transforma el sabor agrio y amargo en dulce. El objetivo fue analizar la respuesta en la percepción del sabor de la
Lizbeth López ${ }^{1}$, Marcela Vela' ${ }^{1}$ Isabel Ibarra², Luisa Díaz ${ }^{3}$, Leticia Belmont ${ }^{1}$, Sara Guillén ${ }^{1 *}$.

1. Laboratorio de Errores Innatos del Metabolismo y Tamiz. Instituto Nacional de Pediatría, Secretaría de Salud de México, Ciudad de México, México.

2. Instituto de Investigaciones Biomédicas UNAM-Instituto Nacional de Pediatría, Secretaría de Salud de México, Ciudad de México, México. 3. Metodología de la Investigación, Instituto Nacional de Pediatría, Secretaría de Salud de México, Ciudad de México, México.

*Corresponding author: Sara Guillen López. Laboratorio de Errores Innatos del Metabolismo y Tamiz, Instituto Nacional de Pediatría, Secretaría de Salud, México.

Av. Imán \#1, piso 1, Col. Insurgentes-Cuicuilco, Delegación Coyoacán, CP 04530. Ciudad de México, México. Email: sara_guillen@hotmail.com

Este trabajo fue recibido el 13 de mayo de 2020. Aceptado con modificaciones: 13 de junio de 2020 . Aceptado para ser publicado: 14 de junio de 2020.

fórmula metabólica con el uso de las tabletas de miraculina en pacientes con EIM y adultos sanos. Se realizó un estudio analítico prospectivo, longitudinal, cuasi-experimental. Los participantes evaluaron la percepción de 3 líquidos (limón, vinagre de manzana y fórmula metabólica) antes y después de la administración de tabletas de miraculina y completaron un cuestionario. Las respuestas sensoriales se evaluaron mediante escalas hedónicas, analizadas con pruebas no paramétricas para datos pareados. Se incluyeron 7 pacientes con EIM y 14 adultos sanos. Después de la miraculina el $57 \%$ de los pacientes $(Z \leq-1,89 p=0,059)$ $y$ adultos sanos $(Z \leq-2,31 p=0,021)$ tuvieron un cambio positivo en su percepción del sabor. La frecuencia absoluta de pacientes a los que no les gustó la fórmula disminuyó 
de 4 a 1, y en quienes les gustó o les encantó, aumentó de 0 a 2 y de 0 a 1 respectivamente; la frecuencia de los pacientes que percibieron la fórmula como indiferente u odiada, no cambió. La respuesta en la percepción del sabor cambió positivamente en el $57 \%$ en ambos grupos. El uso de miraculina puede mejorar la palatabilidad de la fórmula metabólica.

Palabras clave: Errores Innatos del metabolismo; Fórmula metabólica; Fruta milagrosa; Palatabilidad; Synsepalum dulcificum.

\section{INTRODUCTION}

Inborn errors of metabolism (IEM) of proteins are chronic and complex monogenic disorders where an enzyme needed to metabolize amino acids is missing 1 . Without treatment, toxic metabolites could accumulate leading to detrimental effects in different organs and tissues, such as the nervous system, and in some cases may even lead to death ${ }^{1,2}$. To prevent health damage, patients must follow a lifelong diet that is limited of natural proteins and supplementation with amino acid based formulas or medical foods devoid of the offending amino acid or amino acids. The medical foods are needed in order to provide adequate energy and protein requirements ${ }^{1,3,4}$. Adherence to the diet has been reported to be difficult and poor during adolescence and adulthood ${ }^{5,6,7}$, in part due to the bitter, sour, and metallic taste of medical formulas, which are extensively hydrolyzed ${ }^{8,9,10,11}$. Few reports published have addressed palatability of amino acid-based formulas such as the metabolic formula ${ }^{12}$; some of them have documented low palatability and acceptance ${ }^{8,13}$. Thus, new options are needed to improve the taste perception of the metabolic formulas and thereby contribute to better compliance for patients who require their use.

Synsepalum dulcificum, (synonym of Richardella dulcifica) or "miracle fruit" is known for its ability to modify the taste perception of sour foods into a sweet taste ${ }^{14}$. The sweet effect acts not only on sour foods but also on mixtures containing a sour substance ${ }^{15}$. The active ingredient in the miracle fruit is a glycoprotein of 191 amino acids with two $\mathrm{N}$-glycosylation sites called miraculin ${ }^{16,17}$. As little as $100 \mu \mathrm{g}$ of miraculin is enough to change the sour taste into a sweet one, lasting approximately one hour ${ }^{14}$. Miraculin bounds to the sweet receptor site (hT1R2-hT1R3). As an antagonist at neutral $\mathrm{pH}$, this receptor undergoes a structural change in the presence of protons $\left(\mathrm{H}^{+}\right)$or acidic conditions $(<\mathrm{pH}$ 6.7), functionally changing miraculin into an agonist and evoking a strong sensation of sweetness, at the level of the nervous system ${ }^{18}$.

Some reports have used miraculin in a clinical setting, one of them, used miracle fruit in four pediatric patients with cancer under chemotherapy for two weeks, finding positive changes in food perception in all subjects ${ }^{19}$. Another study of Soares et al. conducted with 23 oncologic patients supplemented with the fruit for the same amount of time, reported an improvement in taste perception in $30 \%$ and $35 \%$ considered that miracle fruit was helpful, indicating a possible alternative in this group of patients ${ }^{20}$. None of the studies mentioned above reported the exact amount of miraculin used, but it is known that the miracle fruit pulp contains $36 \mathrm{mg}$ of pure miraculin ${ }^{21}$. To our knowledge, taste perception of metabolic formulas and the use of miraculin in patients with IEM have not been explored. The present study aimed to analyze the response in the taste perception of the metabolic formula with the use of the miraculin tablets in patients with inherited diseases of protein metabolism.

\section{METHODS AND MATERIALS}

A prospective, longitudinal, quasi-experimental, analytical study was performed.

\section{Subjects}

Seven people ( 3 female and 4 male) with confirmed diagnosis of an IEM, older than 10 years of age, followed at the Metabolic Center of the National Pediatrics Institute under metabolic formula treatment, who declared not to like it were invited to participate. All patients were capable of verbal communication and could read and answer a questionnaire. Patients were invited to participate in the study during their visit to the clinic. Exclusion criteria were restrained to patients that manifested an alteration in taste perception or had a known allergy to fruits. The type of metabolic formula and years of use were recorded (Table 1).

\section{Healthy subjects}

Fourteen healthy adults ( 7 males and 7 females) were recruited to evaluate the effect of the miraculin. None of them had participated in this kind of studies before. Inclusion criteria considered no current smokers and not taking any kind of medication. Subjects with taste perception alterations or fruit allergies were excluded. Both groups performed the same procedure described below.

\section{Ethics}

The study was carried out in accordance with ethical and legal guidelines of the National Pediatrics Institute and the code of ethics of the World Medical Association (Declaration of Helsinki) and was approved by the National Pediatrics Institute Faculty of Human research, Ethics and Biosecurity Committees registered with the number 2018/046. Patients and parents/guardians both signed assent and informed consent, respectively. Healthy subjects also signed informed consent.

\section{Experimental design and Procedures Taste evaluation experiment}

Two researchers performed the test, one explained how to answer the questionnaire and gave all the indications and the other administered the different liquids and miraculin tablets in both groups. All participants assessed 3 different liquids that are commonly known to have an acidic taste: lemon, apple cider vinegar, and the metabolic formula. The $\mathrm{pH}$ of the 3 liquids was quantified with a Corning $\mathrm{pH}$ 
Table 1. Patient demographics, diagnosis and type of metabolic formula.

\begin{tabular}{|c|c|c|c|c|c|}
\hline Patient & Sex & Age & $\begin{array}{c}\text { Time taking } \\
\text { metabolic } \\
\text { formula }\end{array}$ & Type of metabolic formula & Diagnosis \\
\hline 1 & Male & 12 y 2 m & 5 y $8 \mathrm{~m}$ & Leucine free metabolic formula & $\begin{array}{l}\text { Deficiency of 3-hydroxy- } \\
\text { 3-methylglutaryl CoA lyase }\end{array}$ \\
\hline 2 & Female & 23 y $2 \mathrm{~m}$ & $3 y$ & $\begin{array}{l}\text { Nonessential amino acid free } \\
\text { metabolic formula }\end{array}$ & Gyrate Atrophy \\
\hline 3 & Female & 19 y $1 \mathrm{~m}$ & 18 y $9 \mathrm{~m}$ & Leucine free metabolic formula & $\begin{array}{l}\text { Deficiency of 3-hydroxy-3- } \\
\text { methylglutaryl CoA lyase }\end{array}$ \\
\hline 4 & Male & 13 y 2 m & 2 y $3 \mathrm{~m}$ & Methionine free metabolic formula & Gyrate Atrophy \\
\hline 5 & Male & 16 y $6 \mathrm{~m}$ & 16 y $6 \mathrm{~m}$ & Phenylalanine free metabolic formula & Phenylketonuria \\
\hline 6 & Male & 18 y $10 \mathrm{~m}$ & 7 y $3 \mathrm{~m}$ & $\begin{array}{l}\text { Nonessential amino acid free } \\
\text { metabolic formula }\end{array}$ & Homocystinuria \\
\hline
\end{tabular}

meter $440^{\circledR}$, the metabolic formula had a pH of 5.75 , lemon juice 3.27 and apple cider vinegar 2.90. All liquids were purchased from local supermarkets and metabolic formula was bought from Abbott Laboratories ${ }^{\circledR}$.

Sensory evaluation tests were conducted in a single room in which every subject was seated on a chair along with his or her parent or guardian. Tap water was provided ad libitum. None of the participants knew which liquids they tasted, and no information was given regarding the taste of them. All participants were asked not to eat any food 2 hours before the test, no specific restrictions were made to daily diet routines. Participants did not have a strong odor of perfume or any other scent themselves, that could interfere with the test. The instructions for participants were: "You will be tasting 3 different liquids, after testing each liquid, select the answer that best describes the taste of the liquid and then wash your mouth profusely". The pre and post acceptances tests for palatability were evaluated using a 5-point hedonic scale as follows: (1) I hate it, (2) I didn't like it, (3) indifference (4) I liked it, and (5) I loved it ${ }^{22,23}$. The first liquid administrated was the metabolic formula, then the vinegar and finally the lemon juice; 20 milliliters were given in a 90-milliliter disposable small plastic cups with the same color. After participants completed the evaluation of the three liquids, a miraculin fruit tablet of $0.5 \mathrm{~cm}$ of diameter and $0.4 \mathrm{~g}$ (mberry ${ }^{\circledR}$ ingredients: miracle fruit powder, corn starch. My M fruit LLC, USA.) was administered, subjects were asked to dissolve the miraculin as long as they needed, not chewing it and pass it all over their tongue. Once the miraculin tablet was totally dissolved the same instructions described above were given and the 20 milliliters of liquids were administrated in the following order: lemon, vinegar, and metabolic formula. More liquids were administrated if subjects wanted more. The order in which the liquids were administrated in the tasting before the miraculin had an explanation; introducing first the metabolic formula was to have a clear and direct perception of the metabolic formula with no other taste perception interference. In the second part after the miraculin administration; the objective was to activate the miraculin agonist effect in the tasting receptors with liquids with a low $\mathrm{pH}$ and give enough time for this activation, so the metabolic formula could be tasted with an accurate perception. Positive change was defined as any number greater than the one obtained in the first test on the 5 point-hedonic scale and negative change was any smaller number.

\section{Statistical analysis}

Sensory tests were evaluated using the hedonic scale, analyzed with nonparametric tests for paired data with Wilcoxon signed-rank test to determine significance of differences between values $(p<0.05)$.

\section{RESULTS}

A total of 21 participants completed the study; 7 people with IEM and 14 healthy subjects. The mean age of the IEM patients and healthy subjects at the time of the study was 15.8 years (10-23 years) and 31.7 years (22-47 years), respectively. The diagnoses of the patients were: phenylketonuria (2), gyrate atrophy (2), 3-hydroxy-3-methylglutaryl-CoA-lyase deficiency (2) and one patient with homocystinuria. The type of metabolic formula for each patient and the time of intake are shown in Table I, the average time of intake was 9.2 years (3-16.6 years). Two people with IEM that in a previous appointment expressed not liking the metabolic formula were excluded due to not showing up to the clinic the day of the study. One person with IEM was excluded because she reported having knowledge of the miracle fruit tablets and what they do and reported having a mild cold.

Before miraculin intervention, both patients and adults 
disliked the metabolic formula. 2/7 people with IEM indicated that they hated it, 4/7 did not like it and only one reported being indifferent. In healthy adults, 2/14 hated it, 9/14 did not like it and 3/14 reported being indifferent. No people with IEM or healthy subjects liked it or loved it.

Figure 1 shows the change of taste perception of the three liquids after the intervention. After miraculin intake, $4 / 7$ patients $(57 \%)$ and $8 / 14$ healthy subjects $(57 \%)$ had a positive change in their perception of the metabolic formula. The absolute frequency of the miraculin test with metabolic formula in patients and adults is depicted in figure 2 . The number of patients who did not like metabolic formula decreased from 4 to 1 , and patients who liked it or loved it increased from 0 to 2 and from 0 to 1 respectively; the frequency of patients who reported being indifferent to the taste of the metabolic formula or who reported hating it, did not change. The Wilcoxon signed-rank test was performed; in the group of patients the $p$-value of metabolic formula shows a clear tendency towards statistical significance $(Z \leq$ $-1.89 p=0.059)$ whereas in healthy subjects group $p$-value was statistically significant $(\mathrm{Z} \leq-2.31 \mathrm{p}=0.021)$. No serious adverse effects, such as allergies, vomiting or diarrhea were reported; mild nausea during the test was documented in one patient, but the subject was able to complete the test.

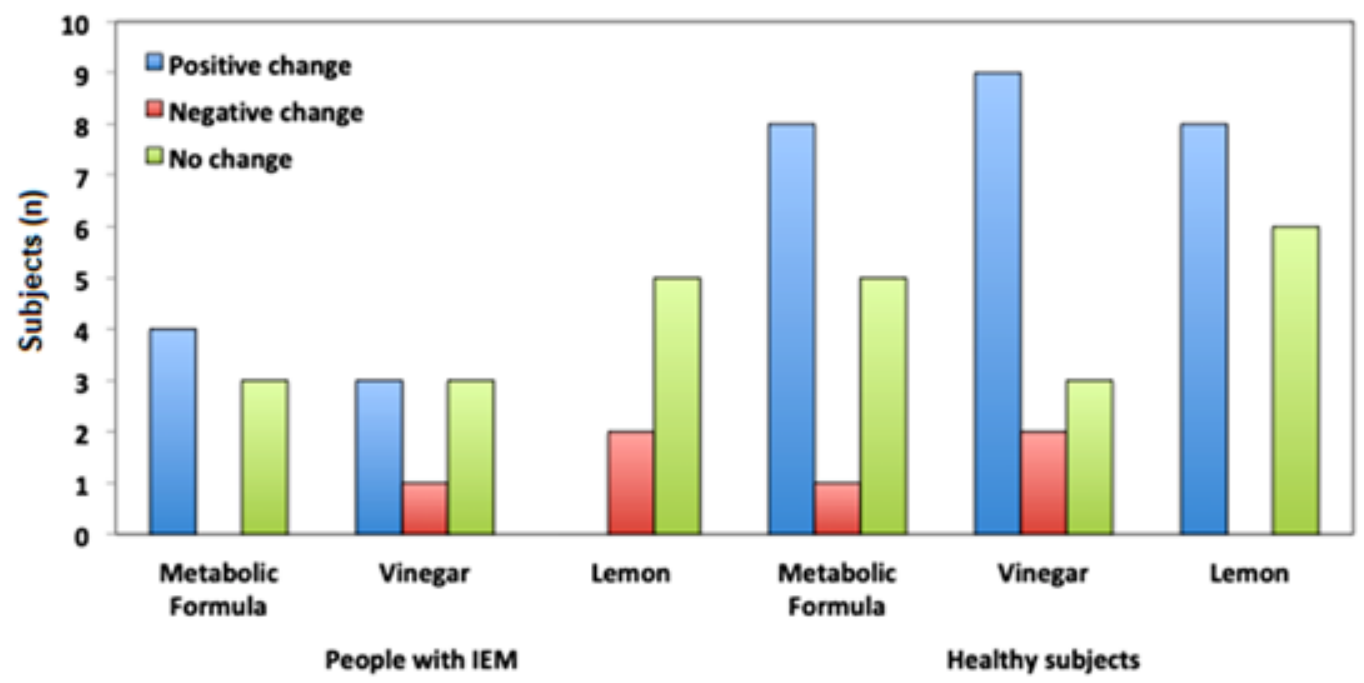

Figure 1: Positive and negative changes in taste perception after miraculin intervention in people with IEM (n:7) and healthy subjects (n: 14).

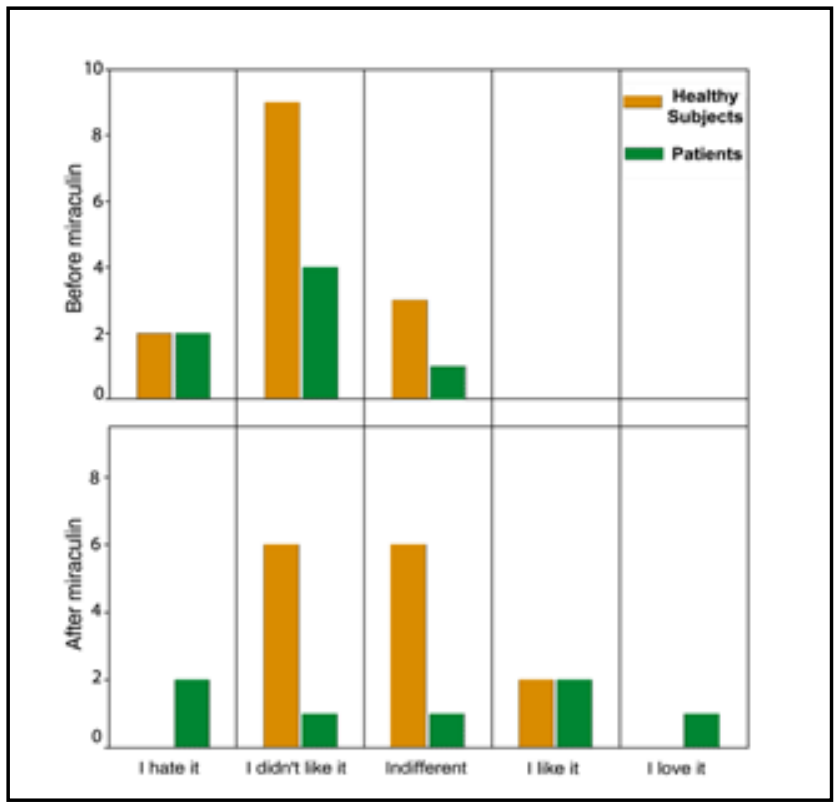

Figure 2: Absolute frequencies of the palatability of the metabolic formula in people with IEM and healthy subjects before and after miraculin. 


\section{DISCUSSION}

To the best to our knowledge, this is the first study that explores the use of miraculin to improve taste perception of the metabolic formulas in patients with IEM. Our main results showed that after miraculin intake $4 / 7$ patients (57\%) and $8 / 14(57.1 \%)$ adults improved their taste perception of the metabolic formula. One patient even reported an important taste change from being indifferent to loving it. The frequency of patients that reported hating the formula $(2 / 7,28.6 \%)$ and being indifferent $(1 / 7,14.3 \%)$ did not change, whereas the number of patients that reported not liking the formula decreased; therefore, more patients reported liking and loving it (Figure 2). The strength of this work was the novelty of investigating the relation between metabolic formula and palatability in the presence of miraculin.

Diet management to correct imbalances in patients with disorders of amino acid metabolism requires the use of medical formulas. Amino acid-based formulas are reported to have an unpleasant taste in general $\left.\right|^{8,9,10,11}$ and the unpleasant taste can be one of the factors that influence adherence failures to the treatment. Options to improve adherence to the nutritional treatment of patients with IEM, are very limited, such as drinking the metabolic formula very cold and changing the taste using artificial flavors, adding fresh or canned fruits, and sugar, among others ${ }^{2}$. Therefore, as our results show, the use of miraculin may be a beneficial alternative to improve the taste perception of the metabolic formula.

Furthermore, currently in some IEM, like PKU, nutritional alterations have been reported in part due to a high carbohydrate intake, such as overweight ${ }^{24}$. So nonartificial and more natural non-caloric sweeteners such as miraculin may be an attractive alternative.

The fact that patients reported to hate and dislike the formula versus the healthy adults that simply reported not to like it, is one of the main reasons why a solution or alternatives to improve compliance must be studied. Something that could explain the dislike of the formula in both groups, (Figure 1) was the fact that many taste buds of the tongue are also located on the palate, throat, epiglottis, and esophagus ${ }^{25}$. Thus, the local effect of the miraculin tablet may not have been sufficient to overcome taste perception in other areas.

Patients with IEM might also present alterations in perception or different preferences; for example, in MMA patients sometimes prefer salty flavors, possibly in association with increased urinary losses ${ }^{26}$. Liem et $\mathrm{al}^{27}$ reported that children who were fed protein hydrolysate formulas their first year of life preferred higher levels of citric acid in juice and also less frequently reported preferences for sweetened juices, when compared to children fed a milk-based formula. It has been shown that infants fed on formulas with a bitter taste (hydrolyzed protein) from birth, eat more savory, bitter and sour-tasting foods after weaning than those given sweeter tasting milk-based formulas or breast milk ${ }^{28}$. Also, MacDonald. et al ${ }^{29}$ reported that PKU children disliked sweet flavors, possibly because of altered taste perception associated with the taste of L-amino acids in the protein substitutes and also parental pressure to eat these types of foods. The preference for the sweet taste is present in early stages of life, continues in childhood, and starts to decrease in adolescence ${ }^{30}$. This may explain why many adults in our study (Figure 1) considered bitter and sour tastes as pleasant and showed a positive change in perceived lemon juice after miraculin intake $(Z \leq-2.64 p=$ 0.008). Rejection to bitter taste is especially present during childhood, a fact that has been related to an evolutionary protection mechanism against foods with toxins ${ }^{31}$. Taste preferences are also influenced by genetic variations and cultural differences ${ }^{32}$.

Among all the patients studied, the majority started taking the metabolic formula after 4 months of age (Table I), with just three patients having started the formula within the period of 0-4 months. Only one patient reported being indifferent towards it, while the rest of the patients who started the metabolic formula after 4 months reported not to like it or hating it. The first months of life have been described as a sensitive period for the establishment of flavor preferences, thus formulas made with hydrolyzed protein are better accepted by infants from 0 to 4 months in comparison to older children and adults ${ }^{33}$. It has also been reported that infants that drink amino acid-based formulas continue to accept it after 5 months old, but this was not the case in our study, with only one patient reporting acceptance ${ }^{34}$.

The intake time of metabolic formula varied, with patients that took the metabolic formula for less than 4 years being the ones who stated hating. These patients also had the same diagnosis; gyrate atrophy (Table 1). The main limitation of this study was the small number of patients included. Another limitation was that we did not take into account the possibility that certain regions of the studied patient's brains such as grey matter that are involved in the hedonic evaluation of tastes might have been compromised as a result of the toxic metabolites damage produced in IEM. Interestingly, it is known that in PKU patients, catecholamine synthesis is impaired due to low levels of tyrosine which is a precursor of noradrenaline, adrenaline and dopamine ${ }^{35}$. Some authors have reported that the catecholaminergic lesion of the ventromedial prefrontal cortex in rats showed an increased preference of a more concentrated solution of glucose, needing stronger stimuli ${ }^{36}$. This might explain the response of one PKU patient who reported indifference before and after the miraculin test (Figure 2).

Improving the taste of metabolic formulas for patients with IEM should facilitate dietary treatment. Longitudinal studies will provide more information to measure applicability and effectiveness and also a possible improvement in compliance. The results of this study might be applicable in other scenarios, where an amino acid-based formula is needed, such as patients with allergies. Further research is needed to compare the effect of miraculin with other options currently available to change palatability. 
The response in palatability showed an improvement of $57 \%$ in patients with IEM and in healthy adults. Miraculin tablets may be an alternative option to change palatability of metabolic formula. More studies are needed to determine the use of the miraculin in IEM patients and its possible impact in compliance.

Acknowledgments: We thank the patients and also the healthy subjects for participating in the study. This work was supported by Research Funding from the Instituto Nacional de Pediatría ("Recursos Fiscales del Programa E022") Ministry of Health, México. LML, MVA, IIG, LDG, $L B M, S G L$ declare no conflicts of interest.

\section{REFERENCES}

1. Camp KM, Lloyd-Puryear MA, Yao L, Groft SC, Parisi $M A$, Mulberg $A$, et al. Expanding research to provide an evidence base for nutritional interventions for the management of inborn errors of metabolism. Mol Genet Metab. 2013; 109: 319-328.

2. Acosta, PB. Nutrition management of patients with inherited metabolic disorders: rationales for and practical aspects of nutrition management. Jones and Barlett., 1st ed. Sudbury, MA, 2012.

3. Camp KM, Lloyd-Puryear MA, Huntington KL. Nutritional treatment for inborn errors of metabolism: indications, regulations, and availability of medical foods and dietary supplements using phenylketonuria as an example. Mol Genet Metab. 2012; 107: 3-9.

4. Leonard JV. The nutritional management of urea cycle disorders. J Pediatr. 2001; 138: 40-45.

5. Medford E, Dougal JH, Wittkowski A. Demographic and psychosocial influences on treatment adherence for children and adolescence with PKU: A systematic review. IIMD Rep. 2018; 39:107-116.

6. Jurecki ER, Cederbaum S, Kopesky J, Perry K, Rohr F, Sanchez-Valle A, et al. Adherence to clinic recommendations among patients with phenylketonuria in the United States. Mol Genet Metab. 2017; 120: 190-197.

7. García MI, Araya G, Coo S, Waisbren SE, de la Parra A. Treatment adherence during childhood in individuals with phenylketonuria: early signs of treatment discontinuation. Mol Genet Metab Rep. 2017; 11: 54-58.

8. Miraglia Del Giudice M, D’Auria E, Peroni D, Palazzo S, Radaelli G, Comberiati $P$, et al. Flavor, relative palatability and components of cow's milk hydrolyzed formulas and amino acid-based formula. Ital J Pediatr. 2015; 41-42.

9. MacDonald A, van Rijn M, Feillet F, Lund AM, Bernstein L, Bosch AM, et al. Adherence issues in inherited metabolic disorders treated by low natural protein diets. Ann Nutr Metab. 2012; 61: 289-295.

10. Ney DM, Gleason ST, van Calcar SC, MacLeod EL, Nelson $K L$, Etzel MR, et al. Nutritional management of PKU with glycomacropeptide from cheese whey. I Inherit Metab Dis. 2009; 32: 32-39.

11. Ney DM, Etzel MR. Designing medical foods for inherited metabolic disorders: why intact protein is superior to amino acids. Curr Opin Biotechnol. 2017; 44: 39-45.

12. Owada M, Aoki K, Kitagawa T. Taste preferences and feeding behaviour in children with phenylketonuria on a semisynthetic diet. Eur J Pediatr. 2000; 159: 846-850.
13. van Calcar SC, MacLeod EL, Gleason ST, Etzel MR, Clayton MK, Wolff JA, et al. Improved nutritional management of phenylketonuria by using a diet containing glycomacropeptide compared with amino acids. Am J Clin Nutr. 2009; 89: 1068-1077.

14. Brouwer JN, van der Wel H, Francke A, Henning GJ. Miraculin, the sweetness-inducing protein from miracle fruit. Nature. 1968; 220: 373-374.

15. Capitanio A, Lucci G, Tommasi L. Mixing taste illusions: the effect of miraculin on binary and trinary mixtures. J Sens Stud. 2011; 26: 54-61.

16. Igarashi G, Higuchi R, Yamazaki T, Ito N, Ashida I, Miyaoka Y. Differential sweetness of commercial sour liquids elicited by miracle fruit in healthy young adults. Food Sci Technol Int. 2013; 19: 243-249.

17. Swamy KB, Suwaibah AH, Sekaran M, Pichika MR. The clinical effects of Synsepalum dulcificum: a review. I Med Food. 2014; 17: 1165-1169.

18. Misaka, T. Molecular mechanisms of the action of miraculin, a taste-modifying protein. Semin Cell Dev Biol. 2013; 24: 222-225.

19. Wilken MK, Satiroff BA. Pilot study of miracle fruit to improve food palatability for patients receiving chemotherapy. Clin I Oncol Nurs. 2012; 16: E173-E177.

20. Soares HP, Cusnir M, Schwartz MA, Pizzolato JF, Lutzky J, Campbell RJ, et al. Treatment of taste alterations in chemotherapy patients using the miracle fruit: preliminary analysis of a pilot study. J Clin Oncol. 2010; 28: e19523.

21. Kurihara, Y. Characteristics of antisweet substances, sweet proteins, and sweetness-inducing proteins. Crit Rev Food Sci Nutr. 1992; 32: 231-252.

22. Lawless HT, Heymann H. ed. Sensory evaluation of food: principles and practices. New York, Springer Science Business Media LLC., 1999; pp. 430-474.

23. Sancho J, Bota E, De Castro JJ. Introduction to the sensory analysis of food. Barcelona Univesity.,1st ed. Spain, 1999.

24. Rocha J, MacDonald A, Trefz F. Is overweight an issue in phenylketonuria? Mol Genet Metab. 2013; 110: S18-S24.

25. Breslin PA, Spector AC. Mammalian taste perception. Curr Biol. 2008; 18: R148-R155.

26. Evans S, Alroqaiba N, Daly A, Neville C, Davies $P$, MacDonald $A$. Feeding difficulties in children with inherited metabolic disorders: a pilot study. I Hum Nutr Diet. 2012; 25: 209-216.

27. Liem DG, Mennella JA. Sweet and sour preferences during childhood: role of early experiences. Dev Psychobiol. 2002; 41: 388-395.

28. Beauchamp GK, Mennella JA. Early flavor learning and its impact on later feeding behavior. J Pediatr Gastroenterol Nutr. 2009; 48: S25-S30.

29. MacDonald A, Rylance GW, Asplin DA, Hall K, Harris $G$, Booth IW. Feeding problems in young PKU children. Acta Paediatr Suppl. 1994; 407: 73-74.

30. Desor JA, Beauchamp GK. Longitudinal changes in sweet preferences in humans. Physiol Behav. 1987; 39: 639-641.

31. Glendinning $/$. Is the bitter rejection response always adaptive? Physiol Behav. 1994; 56: 1217-1227.

32. Mennella A, Pepino Y, Reed DR. Genetic and environmental determinants of bitter perception and sweet preferences. Pediatrics. 2005; 115: 216-222.

33. Pedrosa M, Pascual CY, Larco JI, Esteban MM. Palatability 
of hydrolysates and other substitution formulas for cow's milk-allergic children: A comparative study of taste, smell, and texture evaluated by healthy volunteers. I Investig Allergol Clin Immunol. 2006; 16: 351-356.

34. Mennella JA, Beuchamp GK. Developmental changes in the infants acceptance of protein-hydrolysate formulas. J Dev Behav Pediatr. 1996; 17: 386-391.
35. Daubner SC, Le T, Wang S. Tyrosine hydroxylase and regulation of dopamine synthesis. Arch Biochem Biophys. 2011; 508: 1-12.

36. Beáta B, Kertes E, Péczely L, Ollmann T, Lázlo K, Gálosi $R$, et al. Ventromedial prefrontal cortex is involved in preference and hedonic evaluation of tastes. Behav Brain Res. 2019; 367: 149-157. 